\title{
Japanese Shakudo
}

\section{ITS HISTORY, PROPERTIES AND PRODUCTION FROM GOLD-CONTAINING ALIOYS}

\author{
Hachiro Oguchi \\ Faculty of Fine Arts, Tokyo National University of Fine Arts and Music, Tokyo, Japan
}

\begin{abstract}
Japanese metal art dates from the introduction into Japan of metal working from the Asiatic Continent in the Yayoiperiod (200B.C. to 400 A.D.). Techniques developed gradually, but particularly under Buddhist influence in the Asuka period (540 to 642 A.D.) theyprogressed more rapidlyand the basis of a Japanese traditional metal art emerged in the laterperiod of Nara and Heian (708 to 1184 A.D.).
\end{abstract}

Japanese traditional oriental art is characterized by beautiful ornamentation. Ancient artists were outstanding in the sensitivity of their responses to colour. Indeed, there is a view that this keen perception and appreciation of colour by the Japanese is associated with the blackness of the pupils of their eyes. The early workers in metals in Japan, therefore, searched diligently for methods of preparing materials covering a wider range of colours than those of the natural metals, such as gold, silver and copper and their mixtures, but achieved essentially only modifications of gold yellow, silver white and copper red. They were successful, however, in colouring the surfaces of copper and copper alloys by chemical treatment and, in particular, found that some copperalloys with a low content of gold could be coloured a blueish or purple black by a process involving boiling the alloys in special solutions developed for the purpose.

These surface-coloured copper alloys containing a small percentage of gold are called 'shakudo', which in Japanese means literally 'blackgold'. They havealso been referred to as 'crow's gold' or 'crow's copper' on account of the resemblance of their colour to that of a crow's plumage. Shakudo harmonizes well with golden yellow, silver white and copper red colours and its use contributes materially to the beauty of ancient metal work in Japan.

\section{Shakudo Versus Similar Surface Treated Copper Alloys}

Although the art of surface treating copper alloys in order to produce different colour effectsundoubtedly reached its peak in the production of shakudo inJapan, evidence hasaccumulated in recent years of the practice in the past of similar surface treatments elsewhere. This evidence has been summarized by Craddock (1).

The Department of Conservation of the British Museum recently requested the Museum's Research Laboratory to identify an unusual black deposit on a small Roman plaque. The deposit proved to be cuprite $\mathrm{Cu}_{2} \mathrm{O}$, previously identified in shakudo by Notis (2). It contained small amounts of gold and silver, while the body metal consisted of 92 copper $/ 0.6$ gold $/ 1.2$ silver $/ 1.4 \mathrm{tin} / 1.9 \mathrm{lead} / 1.1$ arsenic/ 0.3 antimony $/ 0.3$ nickel per cent, together with traces of other base metals.

The black coating of cuprite appeared to have been formed in situ by corrosion of this alloy. Craddock was able to provide support for this conclusion from various references in the classical literature, and, on the basis of this and other evidence, put forward the view that Corinthian Bronzes, much sought after in his time according to
Pliny, were essentially surface treated alloys of the shakudo type.

Craddock has also made reference to a suggestion made by Needham (3) that shakudo may be related to the Chinese 'Purple Sheen Gold', so revered by Taoist alchemistsfrom the Han Dynasty onwards, and has speculated on the possibility that a dark alloy known earlier in Tibet as $d z n e-k s i m$ may have been a product of the shakudo type (4).

\section{The Edo and Meiji Periods}

In Japan, shakudo finds mention in the literature on Japanese swords of the Edo period; thus 'the sword owned by a military commander of Genji(Nasuno-Yoichi in the late Heian period, 12th century) was ornamented with shakudo' (5). One of the oldest examples of shakudo work is a set of sword accessories (Mitokoromono)attributed to Goto Yujo, the famous founder of the Goto-family in the Muromachiperiod(1393 to 1570). In that period and later, in the periods of Momoyama and Edo, shakudo was utilized in various works of art, but found special application in the ornamentation of swords and their accessories, especially sword guards(tsuba), in metal catches (hikite) of sliding doors (fusuma), and in the decoration of metal boxes and other items (Figures 1, 2 and 3). It was used mainly in inlaid form and in combination with gold, silver, copper and shibuichi in order to achieve colour effects. Shibuichi was made from an alloy of copper containing about a quarter of its weight of silver (shibuichi inJapanese means a quarter). The surface of this alloy was coloured brown to bright grey by a treatment similar to that by which shakudo was made from alloys of copper with gold. The basic alloys for production of shibuichi were made originally, like those for production of shakudo, by addition of the precious metal to nigurome (see below).

The methods of manufacturing shakudo and the techniques of working with it were kept secret until the middle of the Edoperiod (ca. 1700). Onlycertainfamilies were involved in its production and use. After the middle of the Edoperiod, however, the techniques of metal working gradually became more widely known and one of the early technical texts on metal working entitled 'Soken Kisho' was published in 1781, the first year of Tenmei (6). 'Soken Kisho' is a treatise in seven volumes on the making of Japanese swords. The greater part of this compilation is devoted to accounts of famous metal workers and the products of their art, but in the fifth volume the materials and techniquesused in making Japanese swords in the 

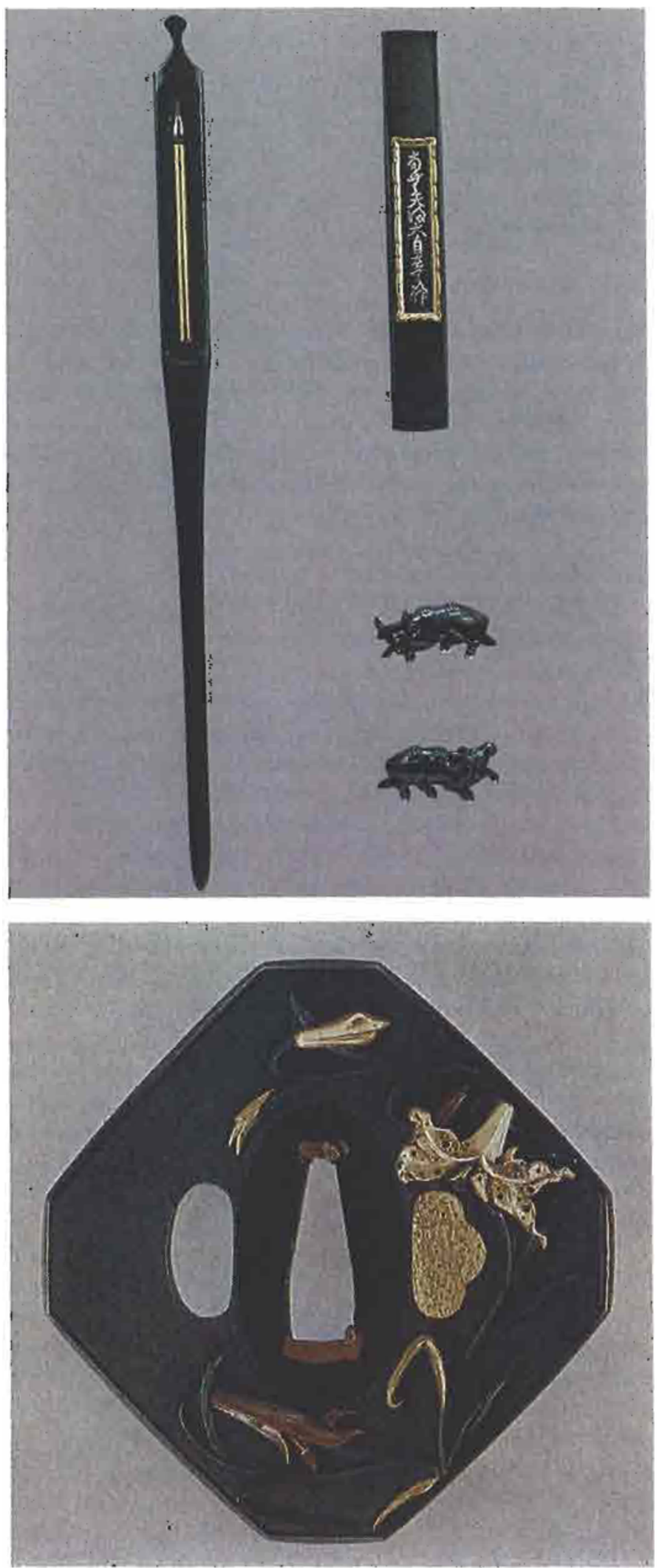

Fig. 1 Set of sword accessories (mitokoro mono) attributed to Gotö-Yüjö. The illustrations show knife (kozaka) and metal rod (kogai) attachments for a sword sheath, and an ornamental rivet head cover for a sword-hilt (menuki), in the form of a pair of oxen in repoussé and partly inlaid with gold. (From 'Illustrated Catalogue' of the Tokyo National University of Fine Arts and Music)

Edo period are described.

These materials and techniques underwent improvement in the Meiji era (1868 to 1912) and practice during this latter period is presented in a monograph entitled 'Kinzoku Seisakuho (Method and Technique of Metal Working)' published in 1937 by Kamezo Shimizu who was then a professor at Tokyo Bijutsu Gakko, which is now the Faculty of Fine Arts of the Tokyo NationalUniversity of Fine Arts and Music (7). This monograph is an invaluable source of information on traditional metal working in Japan, and in it the methods of making and using shakudo are explained. It supersedes an earlier monographon the subject namely 'ShikisaiChokinJyutsu' which was published in 1913 (8).

\section{Manufacture of Shakudo Alloys}

In both the Edo and Meiji periods three types or qualities of shakudo can be distinguished which differ in their gold contents (Table I). In addition during each period a lower quality substitute was made which contained no gold. In the Edo period it wasknown as nigurome, while in the Meiji period it was known as kuromido. The gold content of each quality of Meiji shakudo is smaller than that of the corresponding quality of the Edo type. This most significant difference between the different qualities as reflected in the formulae of the Edo and Meiji periods, respectively, lies, however, in the fact that during the Edo period the basic material specified for making shakudo was nigurome or 'blackcopper', whereas in the Meiji period the use of copper itself was specified. Nigurome was made as is indicated by melting copper with a small amount of shirom $i$ which is a complex white alloy containing arsenic, iron and other impurities. Shiromi is formed during the smelting of raw copper.

In making shakudo, the copper was first melted in a carbon crucible heated in a furnace using charcoal made from specially selected wood. The gold, in suitable quantity, was then added in the form of pieces of foil and the mixture stirred well to ensure it was homogeneous. Lastly, shiromi was added in predetermined amount if it was wanted and the liquid shakudo alloy heated and stirred until itssurface wasclear and mirror like. The liquid shakudoalloy was then poured into an ingot mouldstanding in hot water ( $y u d o k o$ ) at about the temperature of tea $\left(70^{\circ} \mathrm{C}\right)$. Under these conditions the crystal grains of the alloy grow in suitable size and shape for further working of the material. A critical aspect of the whole smelting process was

Fig. 2 Japanese sword guard, in a lilly design, by Tsu-Jimpo (1721-1762). (From 'Illustrated Catalogue' of the Tokyo National University of Fine Arts and Music). Actual size 


\begin{tabular}{|c|c|c|c|c|c|}
\hline \multicolumn{6}{|c|}{$\begin{array}{c}\text { Tablel } \\
\text { Components Used in Making Shakudo of Different Ranks } \\
\text { or Qualities and in Making Nigurome and Kuromido }\end{array}$} \\
\hline \multirow[b]{3}{*}{ Period } & \multirow[b]{3}{*}{ Component } & \multicolumn{4}{|c|}{ Parts by weight } \\
\hline & & \multicolumn{4}{|c|}{ Shakudo Rank } \\
\hline & & High & Middle & Low & $\begin{array}{c}\text { Nigurome } \\
\text { (Edo) or } \\
\text { Kuromido } \\
\text { (Meiji) }\end{array}$ \\
\hline \multirow{3}{*}{ Edo } & Gold & $6-7$ & 3-4 & 1 & - \\
\hline & $\begin{array}{l}\text { Nigurome } \\
\text { Copper }\end{array}$ & $\begin{array}{c}100 \\
-\end{array}$ & 100 & $\begin{array}{l}100 \\
-\end{array}$ & $\overline{100}$ \\
\hline & Shiromi & 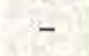 & - & - & 2 \\
\hline \multirow{6}{*}{ Meiji } & Gold & 5 & $2.5-3.0$ & 1 & - \\
\hline & Copper & 100 & 100 & 100 & 100 \\
\hline & Silver & - & & 1 & - \\
\hline & Shiromi & - & - & 1 & - \\
\hline & Shiromi & - & - & 5 & 3 \\
\hline & (Azuki) & & & & \\
\hline
\end{tabular}

the selection of the charcoal for heating the furnace. If the charcoal was of bad quality, the final shakudocolouring would be a distasteful grey and would not have the desirable glossy black tone.

The shakudo alloy ingot was converted to sheet or plate form by hammering or pressing and finally annealed by heating it to about $650^{\circ} \mathrm{C}$, under which conditions it underwent rapid recrystallization with stress relief. Fordecorative purposes it was usuallysurface treated by boiling in an appropriate solution or alternatively it was fire gilded. The fire gilding of shakudo alloy and other metals using the amalgam process is a traditional technique of Japanese metal workers and dates back to ancient times.

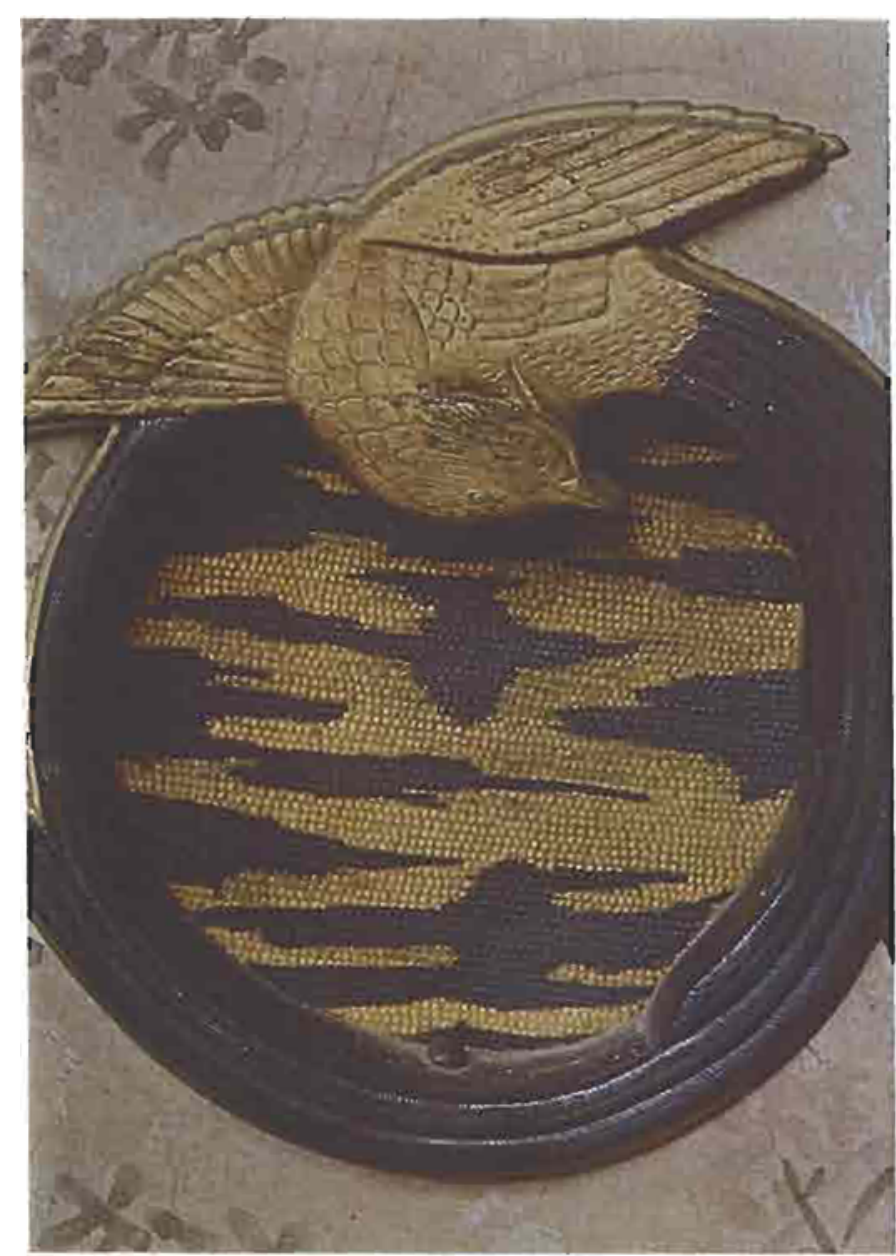

Fig. 3 Metal catch (fusama) of sliding door (nikite) from the early Edo period. Approximately full size
Fig. 4 Microstructure of shakudo containing 5\% gold

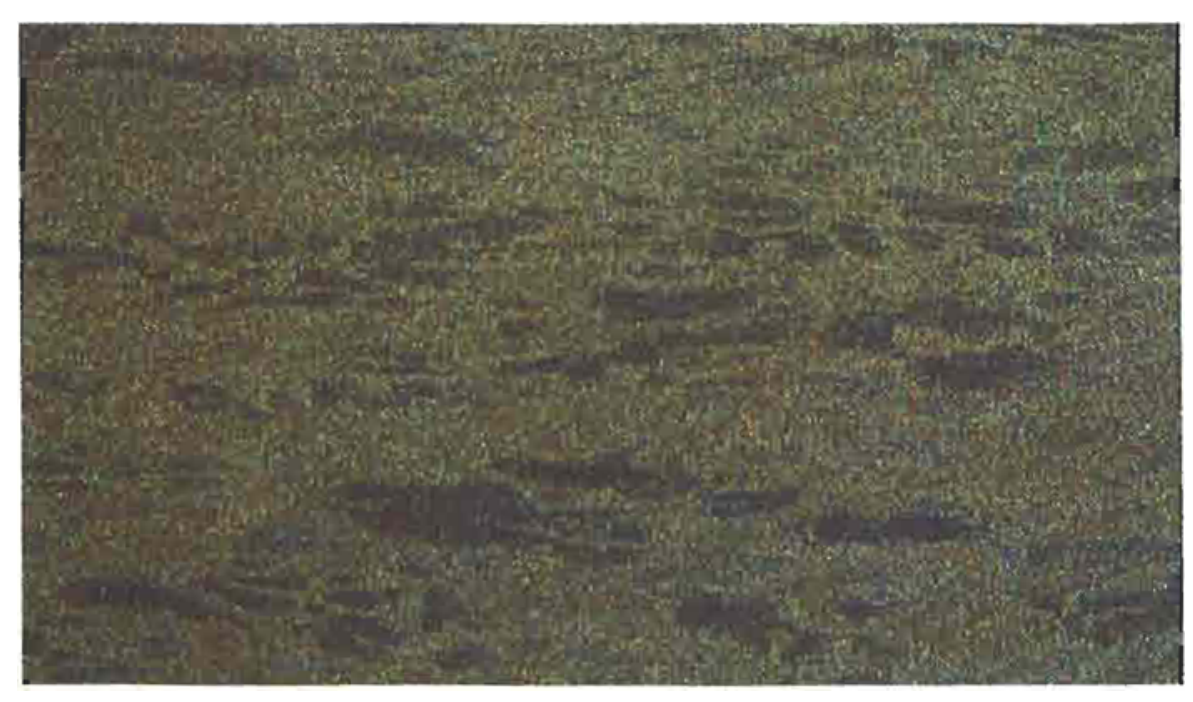

Gold Bull , 1983, 16, (4) 


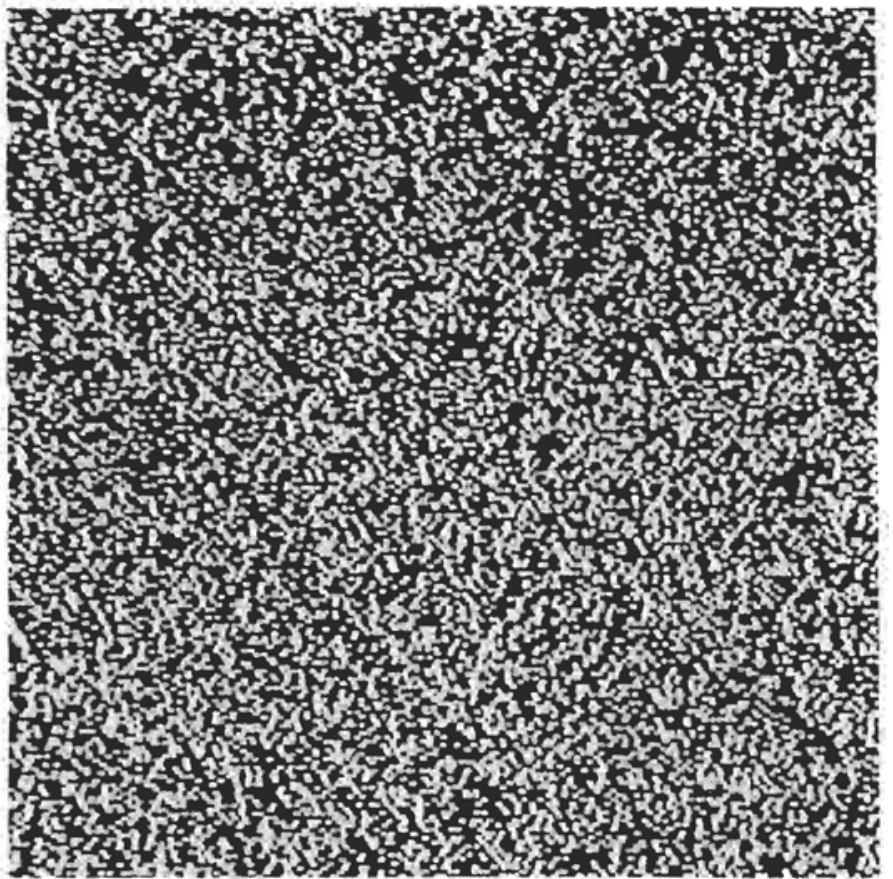

Fig. 5 Characteristic X-ray (CuK $\left.\alpha_{1}\right)$ image of shakudo used in the later Edo period using an accelerating voltage of $25 \mathrm{kV}$, absorbed current of $6 \times 10^{-8} \mathrm{~A}$ with an $\mathrm{LiF}$ analysing crystal. The intensity of $\mathrm{CuK} \alpha$, was 1195250 counts/100 s (scanning period of the photograph being $25 \mathrm{~s}$ )

$\times 1600$

Fig. 6 Characteristic X-ray (AuL $\left.\alpha_{1}\right)$ image of shakudo used in the Edo period. Accelerating voltage, absorbed current and analysing crystal are the same as those used for Fig. 5. Intensity of $A u L \alpha_{1}$ is 15120 counts $/ 100 \mathrm{~s}$ (scanning period of the photograph being $100 \mathrm{~s}$ ) $\times 1600$

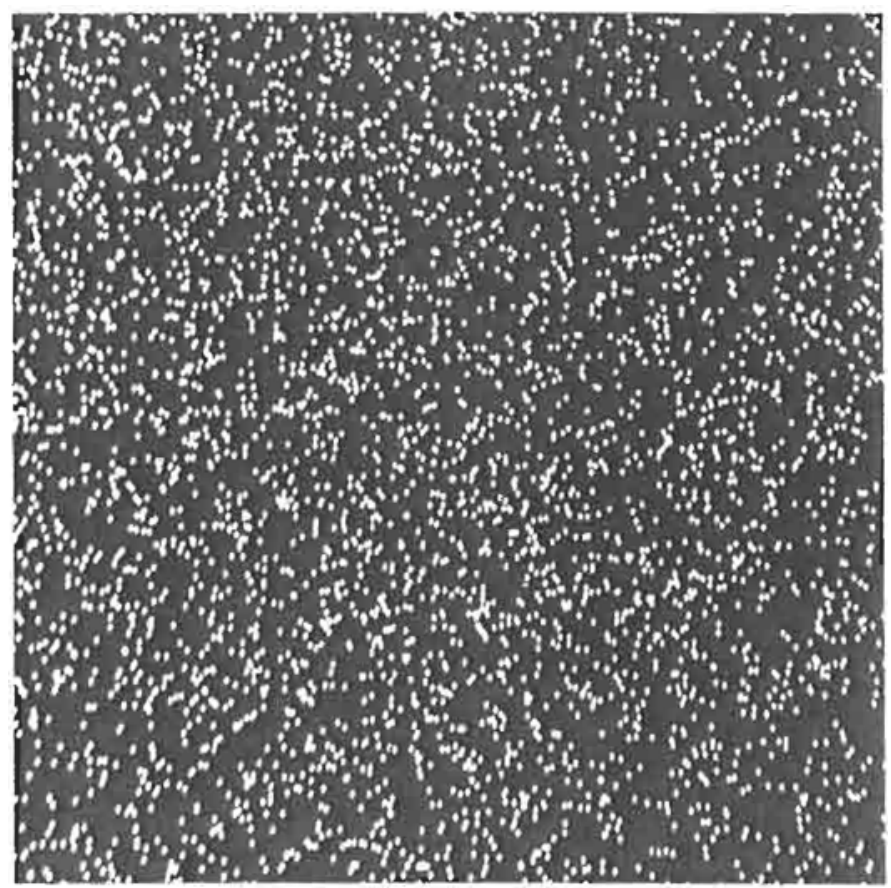

\section{Metallography of Shakudo Alloys}

The microstructure ofaningot of shakudoalloy is dendritic and the crystal grains of shakudo alloy plate after annealing are very similar to those of copper plate. The constitution of the alloy is that of a solid solution as is to be expected from the gold-copper phase diagram,

The microgxaph shown in Figure 4 shows the grain structure of ashakudo alloy sample of high quality or tank containing 5 petcent of gold. The distribution of gold atoms in solid solution form in shakudo has been confirmed using an electron probe microanalyzer (EPMA). Shakudo used in a Japanese sword guard from the Edo period was examined by thistechnique. The characteristic $\mathrm{CuK} \alpha$ and AuL $\alpha \mathrm{X}$-ray imagesare shown in Figures 5 and 6 . The AuL $\alpha$ intensity of the Edo shakudo is close to that of a standard shakudo alloy indicating that the gold content of the Edo shakudo is similar to that of the standard (I per cent).

The elongation of shakudo containing small quantities of gold is smaller and its hardness greater than that of pure copper. Nevertheless, its workability is not significantly less than that of copper.

\section{The Art of Making Shakudo}

Surface finishing of shakudo alloy should be performed with scrupulous attention to detail in order to obtain shakudo of a desirable and characteristic colour. It is carried out on the formed object as the last process after inlaying, gilding and other treatments have been completed.

The steps involved are the following:

1. Polishing

2. Cleaning (degreasing)

3. Colouring

4. Final treatment

Polishing isperformed in the same way as the polishing of copper orbrass. First the shakudoalloy isrubbed using a rub-stone of Nagura which is composed of fine particles of quartzite. Secondly, it undergoescharcoal-polishing (sumitogi) in twosteps. The first step is rubbing with a charcoal stick which is made from a branch of Magnolia hypoleuca. The second step is rubbing with a charcoal block of Paulownia. The charcoal of Paulownia issoft and the particles of it produced by rubbing are small. Its use results in a good finish.

If still finer surface finishing of a shakudo alloy is tequired, then, in the Japanese traditional process, a finishing powder which is obtained by rubbing a charcoal block of Paulownia against a hard whetstone or inkstone (suzuri) isused. The charcoal-polishing with this powder is done by brushing or finger-working the surface of the object repeatedly. Alternatively where a specially brilliant surface is needed, the last polishing is applied with a powder which is made by burning astag antler (tsunoko) in a charcoal fire. After polishing, the degreasing of the surface is carried out with sodium bicarbonate. In the Japanese traditional colouring process, aspecial treatment is then applied just before the degreased article is dipped in the boiling 
solution of colouring agent. In this, the object is soaked in a juice of grated daikon (Raphanus sativusvar. raphanistroides, which is a type of radish extensively used as a vegetable in Japan). The aim is to prevent oxidation of the copper surface in the air. As the juice of grated raw daikon has a weak alkaline reaction, it protects the polished surface of the shakudo alloy from premature tarnishing (7). The article made of or embodying the shakudo alloy is then ready for colour finishing.

In the so-called boiling colour finishing (niiro shiage) to produce the final shakudo, the polished, degreased and pretreated alloy object is dipped in a hot solution of a mixture of salts at about $60^{\circ} \mathrm{C}$. The solution is then heated gradually to boiling. Under these conditions a thin film of oxide forms over the surface of the prepared alloy over a period of 30 to 60 minutes.

The compositions of solutionsused for the colouring of shakudo alloys and copper are shown in Table II. Rokusho is an artificial verdigris which is produced from copper by the action of natural vinegar. Copper sulphate in ancient times was used in the form of the naturally occurring mineral (tanpan).

In order to monitor the colouring process, the article was withdrawn at intervals from the boiling colouring solution and its colour-tone examined. If this was unsatisfactory, the surface treatment wascarried out again from the beginning until finally the desired result is achieved.

The colour-tones of shakudo obtained in this manner vary to some extent according to the gold content of the starting alloy. Furthermore, they change with the thickness of the colouring film. Test plates of four copper-gold alloys containing respectively 20, 10 , 5 and 2.5 per cent of gold were surface treated to convert them to shakudo and the reflection spectra of the final test piecesmeasured. The spectra (Figure 7) show that the colour-tones of shakudo with a low content of gold (10 per cent or less) are not substantially different from one other. In practice, however, their colours developed at different rates during the boiling treatment. The colour-tones of shakudo made from alloys with higher contents of gold (20 to 30 percent)are purplish and light. Shakudo of this type is called Mulasaki-Kin or purple gold in Japan.

Shakudo is normally, in a final treatment, coated with a natural wax which is secreted by an insect the Japanese name for which is ibotamushi. The ibota-wax is applied in the molten condition by wiping with a cloth and the thickness of the resulting wax films is about $1 \mu \mathrm{m}$.

\section{Technology of Shakudo Formation}

In an attempt to provide a better understanding of the reactions involved in the more or less traditional method of making shakudo as described above, and to assist in creating a scientifically based technology forshakudo production, Denzo Unomadeanextensive study of the tarnishing of a variety of alloys of the shakudo type in a number of synthetic media and under different conditions (10).
Table II

\section{Compositions of the Solutions Used Traditionally for Generating the Coloured Surface Flims of Shakudo}

\begin{tabular}{|c|c|c|c|}
\hline \multirow[b]{2}{*}{ Material } & \multicolumn{3}{|c|}{ Quantity } \\
\hline & $\begin{array}{c}\text { For shakudo } \\
\text { (Edo) }\end{array}$ & $\begin{array}{c}\text { For shakudo } \\
\text { (Meiji) }\end{array}$ & $\begin{array}{l}\text { Forcopper } \\
\text { (Meiji) }\end{array}$ \\
\hline $\begin{array}{l}\text { Rokushó } \\
\text { (verdigris) }\end{array}$ & $70 \mathrm{~g}$ & $2.1 \mathrm{~g}$ & $3.2 \mathrm{~g}$ \\
\hline $\begin{array}{l}\text { Copper } \\
\text { sulphate }\end{array}$ & $1 \mathrm{~g}$ & $1.2 \mathrm{~g}$ & $3.2 \mathrm{~g}$ \\
\hline Alum & - & $0.2 \mathrm{~g}$ & - \\
\hline Vinegar & $0.1 \ell$ & - & - \\
\hline Water & 18 & $1 P$ & $1 P$ \\
\hline
\end{tabular}

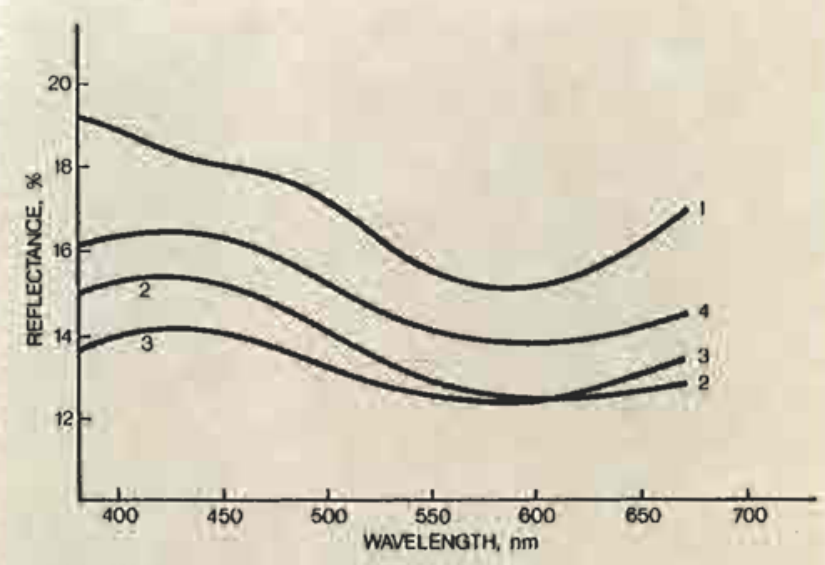

Fig. 7 Reflectance spectra of shakado samples

Shakudo No. $1=80 \mathrm{Cu} / 20 \mathrm{Au} \mathrm{wt} \%$

Shakudo No. $2=90 \mathrm{Cu} / 10 \mathrm{Au}$ wt $\%$

Shakudo No. $3=95 \mathrm{Cu} / 5 \mathrm{Au} \mathrm{wt} \%$

Shakudo No. $4=97.5 \mathrm{Cu} / 2.5 \mathrm{Au}$ wt $\%$

\section{Alloys}

Although early writershadspeculated on the possibility that the impurities in nigurome played a role in the production from it of shakudo, Uno was able to confirm the experience of Miyasawa (11) that shakudo made from electrolytic copper was similar in appearance to that made from nigurome, under identical conditions, but was more uniform in surface texture. Moreover, by corrosion of a series of binary gold-copper alloys of gradually increasing gold content he was able to demonstrate (Table III) the important and in factessential role of gold in determining the colour of the corroded alloy surface. The texture of the alloy was also found to play asignificant role, however, in determining the colour. Because 


\section{Table III}

Colours of the Corroded Surfaces of a Series of GoldCopper Alloys (after Uno(10))

\begin{tabular}{|c|c|c|}
\hline \multirow[b]{2}{*}{$\begin{array}{l}\text { Gold in } \\
\text { alloys, } \\
\%\end{array}$} & \multicolumn{2}{|c|}{ Colour of the corroded surface } \\
\hline & $\begin{array}{c}\text { Grainsize } \\
\text { uncontrolled. } \\
\text { Nothomogenized }\end{array}$ & $\begin{array}{c}\text { Uniformiy small } \\
\text { grainsize. } \\
\text { Homogenized }\end{array}$ \\
\hline $\begin{array}{l}0 \\
0.1 \\
0.5 \\
1 \\
2 \\
3 \\
4 \\
5 \\
6 \\
7 \\
8 \\
9 \\
10\end{array}$ & $\begin{array}{l}\text { red brown } \\
\text { brown } \\
\text { dark brown } \\
\text { blue-grey } \\
\text { dark blue } \\
\text { dark blue } \\
\text { dark blue } \\
\text { dark blue } \\
\text { dark blue } \\
\text { violet } \\
\text { redviolet } \\
\text { bright violet }\end{array}$ & $\begin{array}{l}\text { brown } \\
\text { darkbrown } \\
\text { darkblue } \\
\text { dark blue } \\
\text { darkblue } \\
\text { darkblue } \\
\text { dark blue } \\
\text { dark blue } \\
\text { dark blue } \\
\text { dark blue } \\
\text { blue } \\
\text { blue } \\
\text { blue }\end{array}$ \\
\hline
\end{tabular}
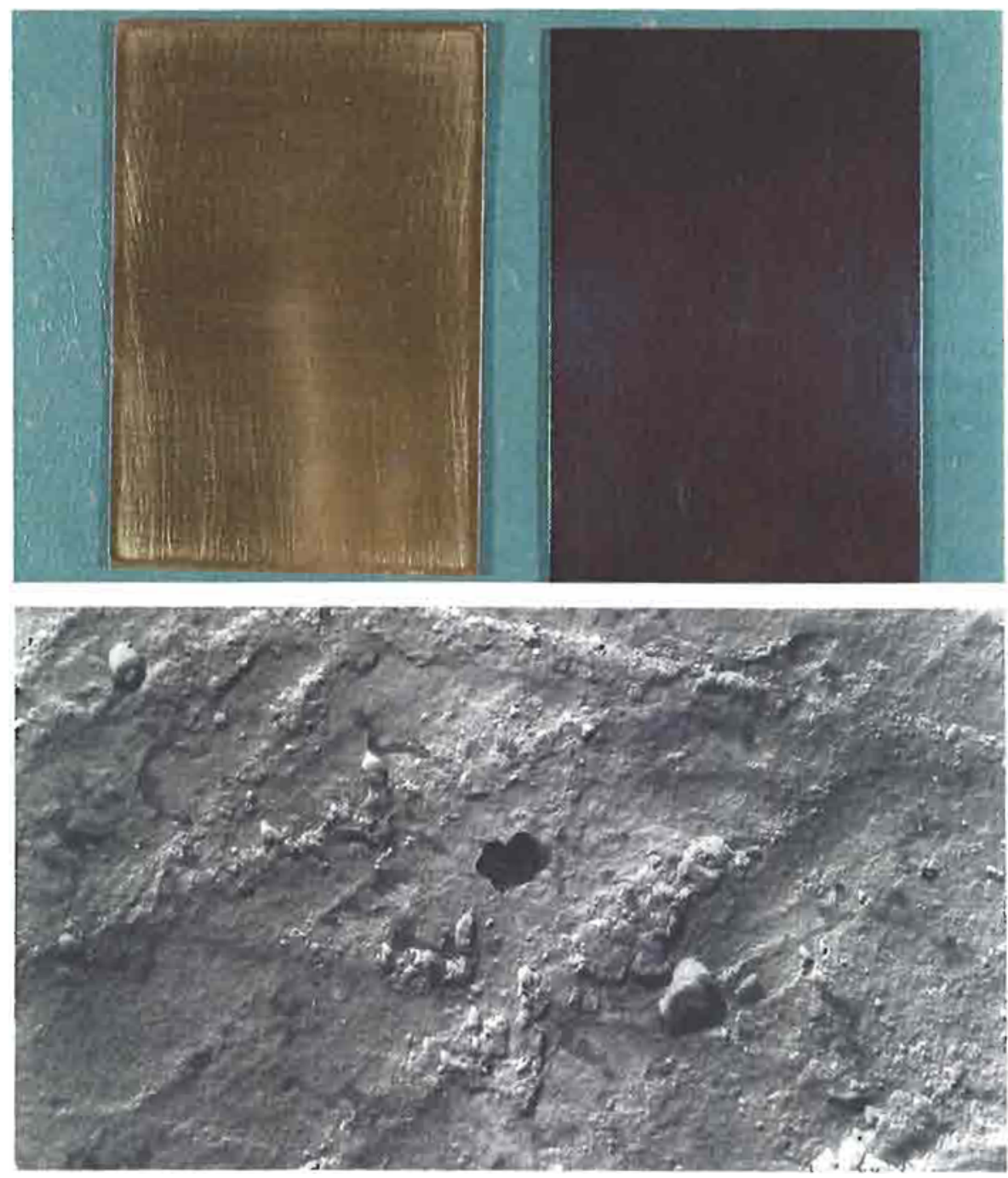

of the separation between the solidus and liquidus curves of goldcopper alloys, the larger crystallites in 'normal' alloys vary in composition and do not tarnish uniformly. If the alloys were first cold worked and annealed three times for 30 minutes at $500^{\circ} \mathrm{C}$, however, the crystallites were smaller and the alloy more homogeneous. Formation of the tarnish film then occurred more uniformly to give surface films of slightly modified colours.

Unoalso experimented with a number of ternary alloys made by additions of up to 5 percent by weight of a series of metals to a binary copper $/ 5$ gold percent alloy. He found, as might be expected, that the surface textures and grain sizes of his ternary alloys were dependent both upon their phase diagrams and their metallurgical histories. By suitable treatment with solutions of various salts, however, it was possible to form upon them coloured surface films very similar to the surface films of shakudo.
Fig. 8 (a) Surface colours of shakudo containing $5 \%$ Au. Full size

Left: Surface colour of shakudo before treatment Right: Black colour of shakudo after treatment
Fig. 8(b) Electron micrograph of black surface of shakudo containing $5 \% \mathrm{Au}$

$\times 35000$ 


\section{Tarnishing Media}

Unfortunately, Uno did not record the corroding medium or the conditions under which the results reproduced in Table III were obtained. He did, however, show that coloured surface films could be formed on shakudo alloys without copper sulphate in the tarnishing medium, whereas it had previously been thought necessary. Healso demonstrated the production of coloured films, using media containing respectively a very wide variety of metallic salts and a wide variety of acids under various conditions.

\section{Shakudo Films}

The black surface of shakudo is smooth and uniform (Figure 8a and $b$ ) but the coloured surface layer is very thin. Its thickness as determinedbyamodification of a method(9) which has been used for determining the thickness of oxidized films on copper was found to be 1.0 to $2.0 \mu \mathrm{m}$.

$\mathrm{X}$-ray diffraction studies by Notis (2) have revealed the presence of only cuprite $\left(\mathrm{Cu}_{2} \mathrm{O}\right)$ in the surface films on shakudo. Electron diffraction patterns obtained by transmission electron microscopy of surface films on shakudo and of surface films of cuprite on pure copper are, however, not identical (See Figures 9 and 10). It seems reasonable to assume that this must be a result of the presence of gold in the shakudo alloy and that this gold in some manner as yet undetermined changes and deepens the colour of the surface films of cuprite on shakudo alloys as compared with those cuprite films on pure copper (1).

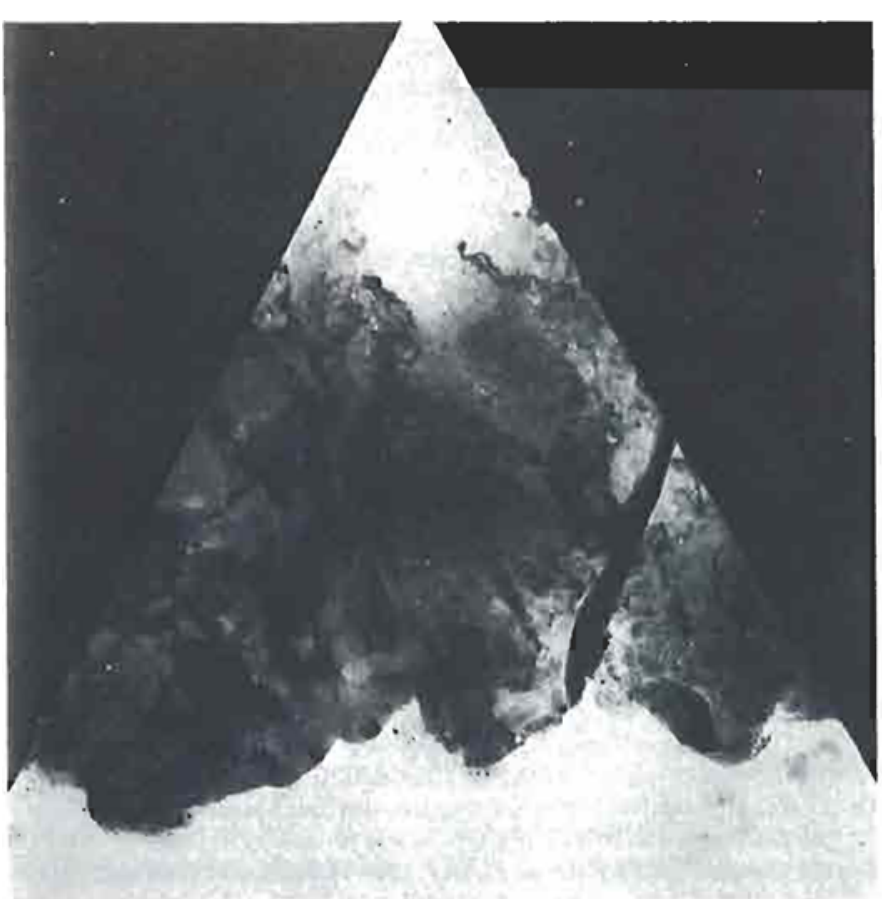

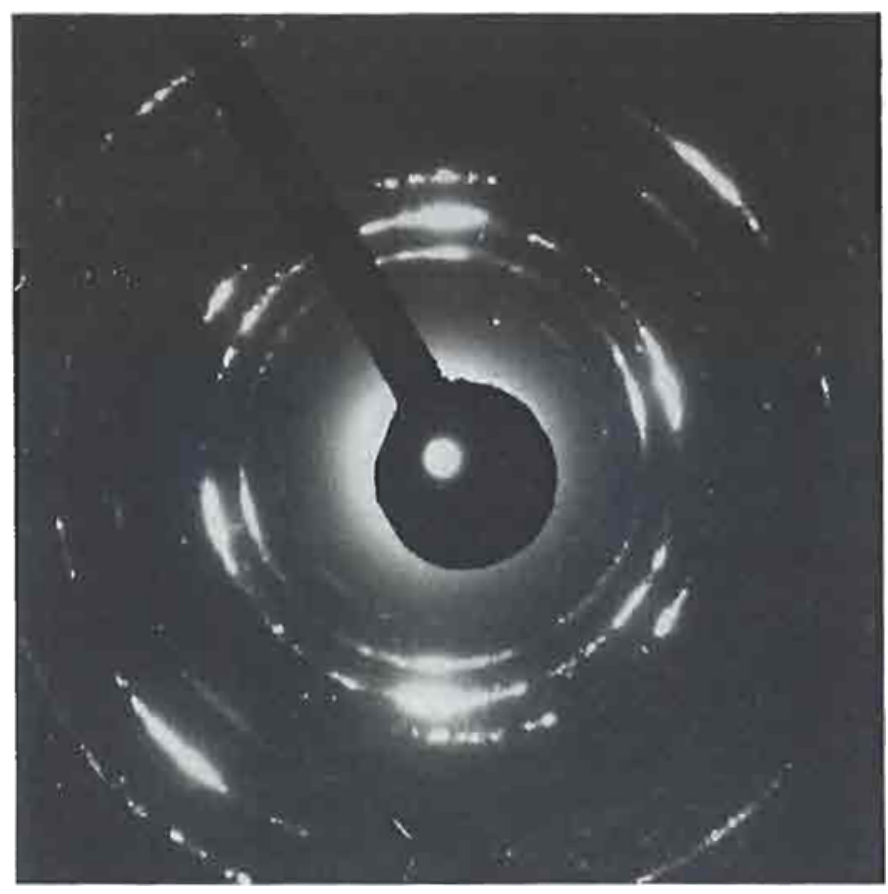

Fig. 9(b) Diffraction pattern of sample shown in Fig. 9(a)

Fig. 10(a) Electron microgrph (selected field) of reddish brown film on copper $\left(\mathrm{Cu}_{2} \mathrm{O}\right)$

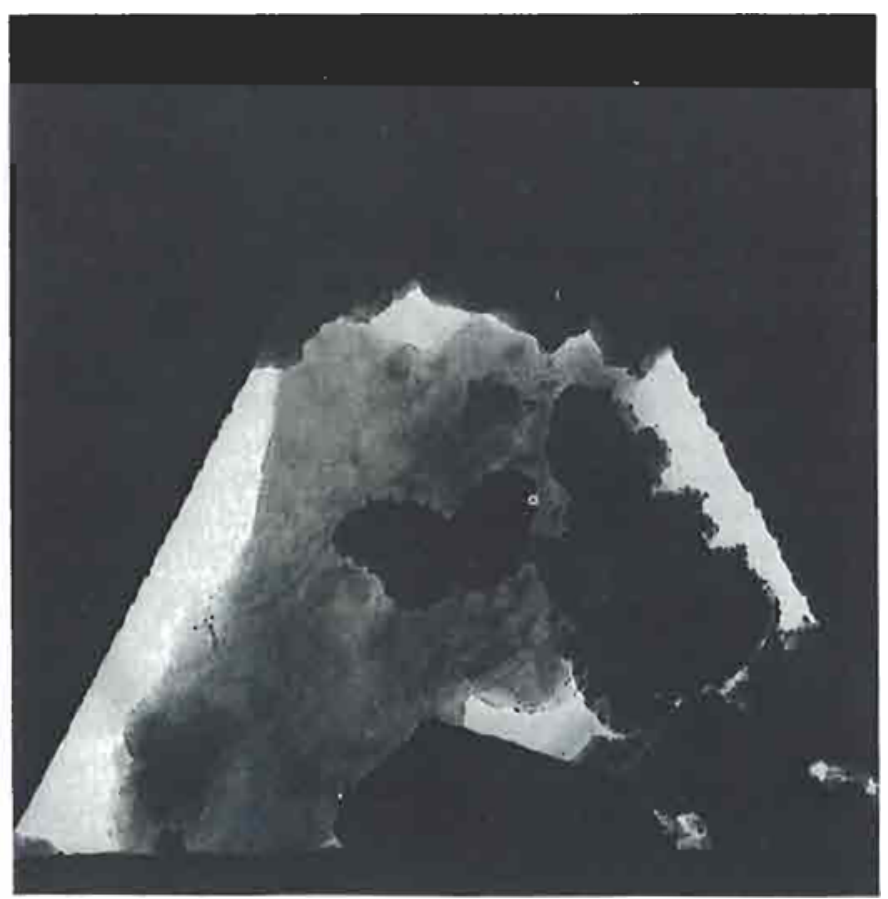




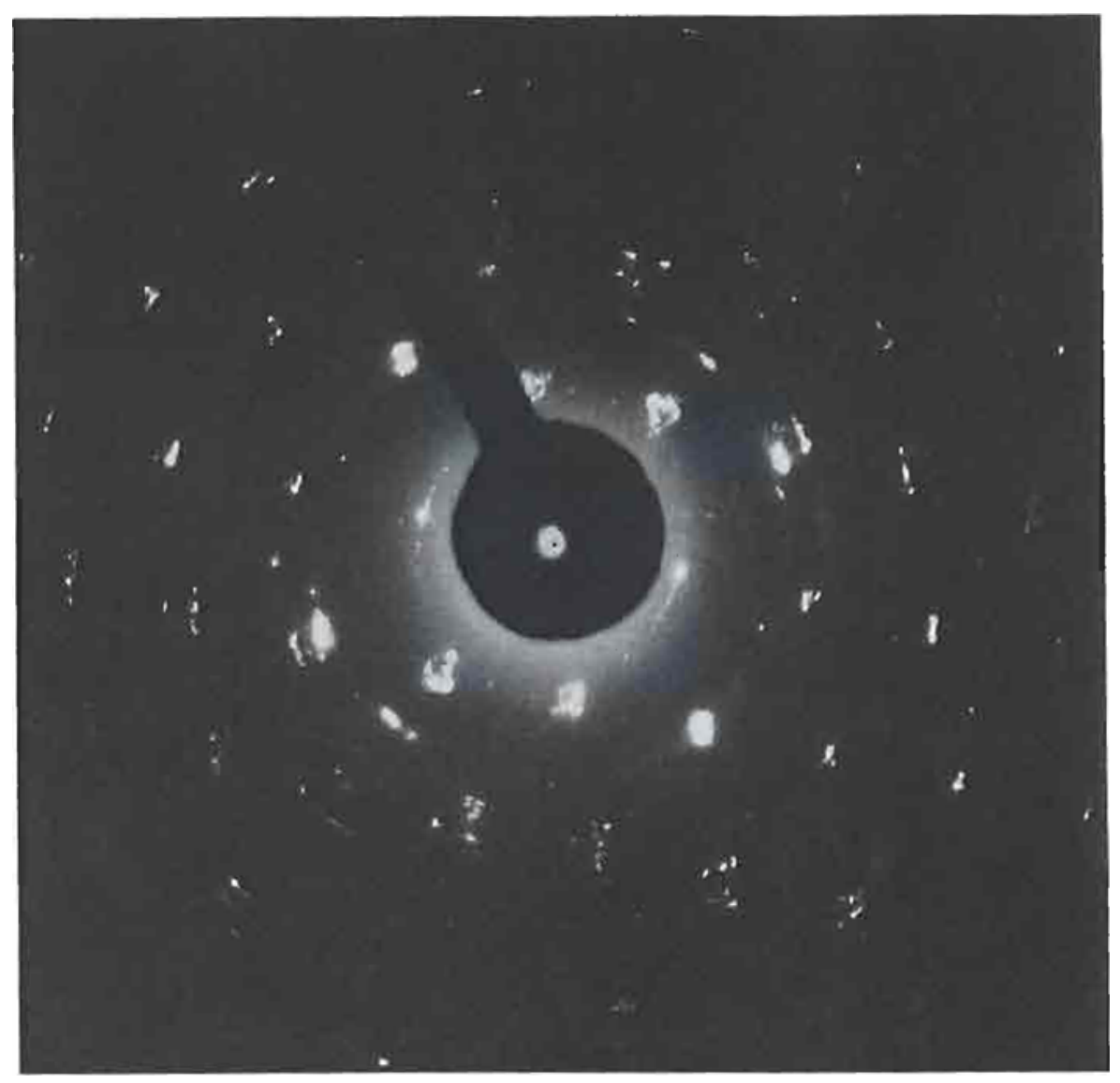

Fig. 10(b) Diffraction pattern of sample shown in the electron micrograph in Fig. 10(a)

The black film of shakudo can change with time. There is a tendency for the thickness of the film to increase with years and for the black colour to deepen in tone.

\section{Mechanism of Film Formation}

There would appear to be no full understanding of the processes by which coloured films are formed upon gold-containing copper alloys in the production of shakudo. There is therefore, scope for further studies of these processes, of the structures of the films themselves, and of the bonding of the films to the substrate alloy.

\section{Summary Remarks}

In Japanese metal arts shakudo was widely used combined with gold and silver in coloured ornamental metal-ware until the Meiji era. In the Japan of today it is not widely used, but has a recognised place in the traditional metal arts and local metal crafts. Our knowledge of the processes involved in shakudo production is still incomplete, but is nevertheless an adequate basis for production of this attractive material on a controlled technological basis. It is still the most beautiful purple black metal which is available to artists and craftsmen and the colour effects that can be achieved using it surpass those which can be achieved with niello which has been known and used from ancient timesin the Orient and in Europe. The author has a keen desire to see shakudo increasingly recognised and used throughout the world.

\section{References}

1 P.T. Craddock, 'Gold in Antique Copper Alloys', Gold Bull., 1982, 15, (2), 69-72

2 M.R. Notis, 'Study of Japanese Mokume Techniques by Electron Microscope Analysis', MASCA J., 1979, 1, (3), 67-69

3 J. Needham, 'Science and Civilization in China', Vol. S, Part 2, Cambridge University Press, 1972, especially pp. 23 and 257.266

4 L.S. Dagyab, 'Tibetan Religious Art. Part I, Texrs', Harrasowitz, Wiesbaden, 1977, especially Chapter 2

5 S. Matsudaera, 'Shüko Jisshu (Commentary on the ten kinds of antiques)', 17 th Century, Japan

6 S. Inaba, 'Söken Kisho', 1781, Japan

7 K. Shimizu, 'Kinkó Seisakuhö', 1937, printed in the Department of Chokin, Tokyo Bijursu Gakko

8 N. Mizuno, 'Shikisai Chökinjutsu(Metal Working and Colouring Technique of Metals)', 1913, 'Tokyo

9 H. Oguchi, 'Experimental Studies on Japanese Traditional Colouring Copper', Bull. Faculty Fine Arts, Tokyo Nat. Univ. Fine Arts and Music, 1972, 63-65

10 D. Uno, 'Künstliche Korrosionvon japanischen Speziallegeirungen', Komosion und Metallschutz, 1929, 5, (6), 121-130 and 147-156

11 S. Miyasawa, Jpn. Ind. Chem. J., 1917, 109-134. See also O. Gowland, J. Inst. Met, , 1910, (2), 4 